\title{
FGFR1OP2 Gene
}

National Cancer Institute

\section{Source}

National Cancer Institute. FGFR1OP2 Gene. NCI Thesaurus. Code C98075.

This gene may be involved in wound responses. 